\title{
The Relationship of Indonesian Language Learning with the Environment
}

\author{
Pangesti Wiwit Nadila/18016171 \\ Padang State University-FBS \\ pangestiwiwitnadilanadila3@gmail.com
}

Environmental problems are currently the most common problems. Environmental problems are caused by the characteristics of humans as economic beings, starting from natural factors and humans themselves. This is in line with Lai (in Ramadhan, Sukma, and Indriani, 2019) stating that humans who live today are faced with environmental problems. Humanity has long been known that its existence depends on the status of the environment (Nazarenko, in Ramadhan, Sukma, and Indriani, 2019). Mitzuki and Nkwetisma (in Ramadhan, Sukma, and Indriani, 2019), everyone has the same responsibility to solve this problem. So, the problems that occur must be immediately sought for a solution because this problem not only affects the future, but also today.

According to Ramadhan, Sukma, and Indriani (2019), around the world many methods have been applied to solve environmental problems, such as government policies to attract the people of the nature-loving movement and strengthen government regulations. However, this method is not effective enough to reduce environmental problems. It takes the development of individuals who are aware and responsible for the environment to overcome this so that environmental problems are sustainable and the quality of life is better. This can be realized through education, more specifically environmental education. Nkwetisma (in Ramadhan, Sukma, and Indriani, 2019) states that environmental education is a collective effort that is consciously organized to teach or attract human attention about how the natural environment functions and how humans can manage and protect that nature.

Efforts to solve environmental problems today are by instilling in the young generation the importance of protecting the environment from an early age. Small things such as not littering, using water as needed, and so on are the first steps you can take. Instilling a sense of responsibility and awareness of protecting the environment can be done in schools by applying environmental materials in learning. One of the lessons that can be related to environmental material is language learning. 
Learning Indonesian cannot be separated from language skills, one of which is writing skills. Writing is the most important skill in education, but writing skill is a difficult skill, compared to other language skills. According to Ramadhan, Indriyani, Asri, and Sukma (2020), writing skills are not skills that are acquired naturally, but are learned. One of the factors that causes students' difficulty in writing is that they are less able to determine topics in writing. According to Amelia, Sukma, and Asma (2015), what can be done to involve students in finding resources in writing is to facilitate students to interact with the environment, so that students can actively participate in protecting the environment. Furthermore, according to Safitri and Sukma (2020), when writing use language that is easy to understand, and use topics related to certain environments.

In learning Indonesian, the teacher must have obstacles in the learning process, especially in the cognitive aspects, namely the lack of understanding of the teacher in teaching (Sukma, 2019). Currently, Indonesian language learning is in the spotlight, because it is based on observations in schools that there are still many teachers who have difficulty teaching literature, including teaching writing rhymes. Therefore the teacher must guide students to be able to write both rhymes, poetry, texts and others. The teacher must provide an attractive teaching model for students. In addition, the use of various learning models can increase students' understanding in learning. According to Habibi, Sukirno, Sukma, Suriani, \& Putera, R. F. (2020), in learning materials to write narrative text, students can write it based on what is happening in the surrounding environment. Literature education itself can hone the skills and creativity of students in the world of literature, but it is also very important for the moral education of students themselves.

According to Ramadhan, Sukma, and Indriani (2019), to overcome this, teachers play an important role in teaching environmental education and fostering student awareness about the environment. According to Buldur and Omeroglu (in Ramadhan, Sukma, and Indriani, 2019), environmental education is important to increase students' attitudes and awareness of the environment. Environmental education should be designed to contribute to the cognitive, emotional, linguistic and psychomotor development of students, and enable them to develop positive attitudes towards the environment. In addition, teachers must also develop students' abilities to understand, criticize, and participate rationally in any discourse about environmental problems. 
Based on the above problems, the authors conducted research on the Relationship between Indonesian Language Learning and the Environment. The research was conducted by making 10 statements in the form of a google form questionnaire. This questionnaire was filled in by students from various departments, semesters, and universities. As many as 58 respondents participated in filling out questionnaires from various universities, such as Padang State University, Andalas University, IAIN Surakarta, West Sumatra PGRI STKIP, UNDHARI, Batam State Polytechnic, Payakumbuh State Agricultural Polytechnic, UIN Sultan Syarif Kasim Riau, Indonesian Islamic University, and Putra Indonesia University.

The results obtained from this study are as follows. The first statement, in Indonesian language learning the role of the environment is very important, which states strongly agree (56.9\%), agree (41.4\%), disagree (1.7\%), and disagree $(0 \%)$. The second statement, environmental material is very closely related to everyday life, which says agree $(50 \%)$, strongly agree $(48.3 \%)$, disagree $(1.7 \%)$, and disagree $(0 \%)$. The third statement, when learning Indonesian the teacher invites students to protect and preserve the environment, who say they strongly agree $(51.7 \%)$, agree $(44.8 \%)$, disagree $(3.5 \%)$, and disagree $(0 \%))$. The fourth statement of the environment can develop the imagination of students in Indonesian language learning, which says agree (50\%), strongly agree (48.3\%), disagree (1.7\%), and disagree $(0 \%)$. The fifth statement, learning Indonesian with the environment can reduce the saturation of students, who say they agree $(51.7 \%)$, strongly agree $(46.6 \%)$, disagree $(1.7 \%)$, and disagree $(0 \%)$.

In the sixth statement, the environment can be used as a learning resource that is fun and useful for students, who say they agree (53.4\%), strongly agree (46.6\%), disagree (0\%), and disagree $(0 \%)$. . The seventh statement, learning Indonesian with the environment can improve the social relations of students, who say they agree $(56.9 \%)$, strongly agree $(43.1 \%)$, disagree $(0 \%)$, and disagree $(0 \%)$. The eighth statement, in learning Indonesian students are able to predict the symptoms that occur in the environment, who say they agree $(69 \%)$, strongly agree $(25.8 \%)$, disagree $(5.2 \%)$, and disagree $(0 \%)$. The ninth statement, learning Indonesian with the environment directly or indirectly fosters students' concern for the environment, who say they agree (63.8\%), strongly agree $(32.8 \%)$, disagree $(3.4 \%)$, and disagree. agree $(0 \%)$. The tenth statement, the teacher provides an understanding of what environmental objects are through the description text, which says agree $(62.1 \%)$, strongly agree $(32.8 \%)$, disagree $(5.2 \%)$, and disagree $(0 \%)$. 
Based on the results of the research conducted by the author, it can be concluded that the relationship between Indonesian language learning and the environment is very necessary. The environment makes it easier for students to understand Indonesian material well, broaden students 'insights, and can build students' ecological intelligence. The environment is closely related to everyday life. Therefore, linking Indonesian language learning with the environment makes it easier for teachers to find relevant examples that make students better understand the material provided, provide comprehensive knowledge and skills in protecting the environment. 


\section{References}

Amelia, Sukma, E., \& Asma. (2015). Pembelajaraan Menulis Laporan Percobaan Dengan Pendekatan Saintifik di Sekolah Dasar. In Prosiding Seminar Nasional Jurusan PGSD FIP UNP Tahun 2015 (Vol. 1, No. 1).

Elsa., Syahrul, R., dan Tressyalina. (2017). Pengaruh Penggunaan Model Discovery Learnig terhadap Keterampilan Menulis Karangan Argumentasi Siswa Kelas X SMA Negeri 3 Pariaman. Jurnal Pendidikan Bahasa dan Sastra Indonesia. Vol. 6, No. 2

Guci, I., Ramadhan, S., Nursaid. 2016. Korelasi Penguasaan Kosakata Bidang Lingkungan Hidup dengan Menulis Karangan Argumentasi tentang Lingkungan Hidup. Jurnal Pendidikan Bahasa dan Sastra Indonesia. Vol. 5 No. 2.

Habibi, M., Sukirno, T., Sukma, E., Suriani, A., \& Putera, R. F. (2020). Direct Writing Activity: A Strategy in Expanding Narrative Writing Skills for Elementary Schools. Universal Journal of Educational Research, 8(10), 4374-4383.

Ramadhan, S., Sukma., \& Indriyani, V. (2019). Enviromental Education and Disaster Mitigation Through Languange Learning. IOP Conference Series: Earth and Evironmental Science, 314, pp 14.

Ramadhan, S., Indriyani, V., Asri, Y., \& Sukma, E. (2020). Design of Learning Modules Writing Narrative Text Based on Project Based Learning (PjBL) by Using Mobile Devices. JPhCS, 1471(1), 012029.

Safitri, A., \& Sukma, E. (2020). Peningkatan Hasil Belajar Siswa pada Tema 3 Menggunakan Pendekatan Saintifik di Sekolah Dasar. Jurnal Pendidikan Tambusai, 4(3), 3132-3144.

Sari, Yuliana., Syahrul, R., dan Yulianti Rasyid. (2018). Hubungan antara Keterampilan Membaca Pemahaman dengan Keterampilan Menulis Teks Laporan Hasil Observasi Siswa Kelas X SMK Negeri 3 Padang. Jurnal Pendidikan Bahasa dan Sastra Indonesia. Vol. 7, No. 3.

Sukma, E. (2019). Problem in Oral Language Teaching in Primary School. Seventh internation conference on languanges and arts (ICLA 2018). Atlantis Press.

Tatalia, R. G., Ramadhan, S., \& Ermanto. (2015). Pengaruh Model Pembelajaran Kooperatif Tipe STAD Berbantuan Pemetaan Pikiran (MIND MAPPING) dengan Mempertimbangkan Motivasi Belajar Terhadap Kemampuan Menulis. Jurnal Bahasa Sastra dan Pembelajaran. 3(1) 36-45. 